\title{
A novel manganese-oxide/biochar composite for efficient removal of lead(II) from aqueous solutions
}

\author{
M. C. Wang $\cdot$ G. D. Sheng $\cdot$ Y. P. Qiu
}

Received: 26 August 2013/Revised: 8 January 2014/ Accepted: 5 March 2014/Published online: 19 March 2014

(C) Islamic Azad University (IAU) 2014

\begin{abstract}
Biochar (BC) derived from pyrolysis of plant biomass can be used as an inexpensive adsorbent for removal of aqueous heavy metals. In the present study, amorphous hydrous manganese oxide was loaded onto BC to fabricate a novel manganese-oxide/biochar $(\mathrm{Mn} / \mathrm{BC})$ composite for further enhancing lead(II) removal by sorption from water. $\mathrm{Mn} / \mathrm{BC}$ was characterized by X-ray diffraction, scanning electron microscope, and specific surface area analysis. After impregnation with $3.65 \% \mathrm{Mn}$, $\mathrm{BC}$ raised the removal efficiency of lead(II) from 6.4 to $98.9 \%$ at $\mathrm{pH} 5.00$. This improvement is attributed to the increase in surface hydroxyls and the decrease in $\mathrm{pH}_{\mathrm{PZC}}$ ( $\mathrm{pH}$ at the point of zero charge) of carbon. The maximum monolayer adsorption of lead(II) on $\mathrm{Mn} / \mathrm{BC}$ at $298 \mathrm{~K}$ was five times that on $\mathrm{BC}$. The smaller pseudo-second-order rate constant of $\mathrm{Mn} / \mathrm{BC}$ compared with that of $\mathrm{BC}$ indicated that the sorption rate of $\mathrm{Mn} / \mathrm{BC}$ is faster than that of BC. The calculated thermodynamic parameters implied that the sorption of lead(II) is a spontaneous and endothermic process. The results suggest that $\mathrm{Mn} / \mathrm{BC}$ composite is a promising adsorbent for the efficient removal of lead(II) from water.
\end{abstract}

Keywords Biochar $\cdot$ Removal $\cdot$ Sorption $\cdot$ Manganese oxide $\cdot \operatorname{Lead}(\mathrm{II})$

M. C. Wang · G. D. Sheng · Y. P. Qiu (凹)

State Key Laboratory of Pollution Control and Resource Reuse,

College of Environmental Science and Engineering, Tongji

University, Shanghai 200092, China

e-mail: ypqiu@tongji.edu.cn

\section{Introduction}

A "green" porous carbon (biochar) has been recently prepared and applied in carbon sequestration to address global warming (Chen et al. 2012; Fraser 2010). This carbon-rich material is produced from the fast thermal decomposition of biomass at oxygen-limited conditions without any steam and/or chemical activation (Wang et al. 2013; Qiu et al. 2009a) and features higher productivity with less energy consumption compared with commercial activated carbon (AC) (Cao et al. 2009). As a more economical carbonaceous adsorbent, biochar (BC) may be a potential AC substitute for the removal of contaminants from wastewater (Kong et al. 2011).

Biochar has a smaller surface area and less porosity than $\mathrm{AC}$ but also features more surface oxygen-containing functional groups (Chun et al. 2004). These characteristics indicate that $\mathrm{BC}$ is more suitable for removing heavy metal pollutants (HMPs) than hydrophobic organic pollutants. Recent studies have confirmed more effective removal or immobilization of $\mathrm{Pb}$ (II), $\mathrm{Cd}(\mathrm{II}), \mathrm{Cu}$ (II), and $\mathrm{Ni}(\mathrm{II})$ by $\mathrm{BC}$ compared with AC (Uchimiya et al. 2011; Qiu et al. 2008). However, the reported sorption capacity of HMPs on BC is not adequately high for actual wastewater treatment applications. To enhance the uptake of HMPs on BC, two improved approaches are applied to functionalize the surface of BC: (1) chemical modification (oxidation) to increase the surface acidity of $\mathrm{BC}$ and (2) introduction of metal oxides onto BC to increase surface hydroxylation. The traditional chemical oxidation method (e.g., by $\mathrm{HNO}_{3}$ ) has apparent negative effects on BC characteristics, including destruction of the rigid matrix structure, decrease in carbon content, and reduction in surface area (Considine et al. 2001). In comparison, loading of hydrated metal oxides onto carbons is a moderate way to effectively raise 
HMP sorption by enhancing electrostatic interactions between the charged HMP species and the hydroxylated metal oxide surface (Vasudevan et al. 2001).

Hydrous manganese oxide (HMO) is applied more widely than hydrous $\mathrm{Fe}$ or $\mathrm{Al}$ oxides due to its stronger affinity for HMPs (Wang et al. 2007). However, the micron-scale size of HMO particles is difficult to use in continuous-flow water treatment devices. In addition, HMO colloids easily agglomerate in waters exposed to solution chemistry conditions. Finally, HMO particles dispersed in aqueous solutions are not easy to collect for regeneration. To overcome these disadvantages and expand the application of HMO in dynamic wastewater treatment, many researchers have considered impregnating amorphous HMO onto various layered and porous structural materials [e.g., montmorillonite (Thipnakarin et al. 2006), zeolite (Han et al. 2006a), polymer resin (Su et al. 2009)]. Carbonaceous materials are the ideal support media for increasing the stability of HMO against aggregation and enhancing its sorption affinity for HMPs (Wang et al. 2007; Fan and Anderson 2005). As BC is a more environmentfriendly and less expensive carbon source compared with $\mathrm{AC}$ and carbon nanotubes, it may be more suitable for use as an HMO support. The number of acid groups per unit surface area of $\mathrm{BC}$ is higher than that of $\mathrm{AC}$, implying that $\mathrm{BC}$ can provide more surface sites (e.g., carboxyl groups) for combination with $\mathrm{Mn}$ (II) and further reaction with oxidants (e.g., potassium permanganate, sodium hypochlorite). Thus, more HMO can disperse and deposit on BC surfaces.

In the present work, we focus on the fabrication and application of BC-supported HMO for the removal of $\mathrm{Pb}$ (II) from aqueous solutions. The objectives of the study are to determine the ability of $\mathrm{HMO}-\mathrm{BC}$ composites for enhanced $\mathrm{Pb}$ (II) uptake and explore the kinetic and thermodynamic sorption mechanisms of $\mathrm{Pb}$ (II) on the HMOloaded BC.

\section{Materials and methods}

\section{Materials}

Analytical grade reagents of potassium permanganate, manganese nitrate, and lead nitrate were purchased from Shanghai Chemical Reagent Company (China). Peeled pine wood (Pinus massoniana) was cut into small pieces $(3 \mathrm{~mm} \times 3 \mathrm{~mm} \times 8 \mathrm{~mm})$ and then placed in a ceramic pot. Pyrolysis of the air-dried wood was conducted in a muffle furnace at $100{ }^{\circ} \mathrm{C}$ for $1 \mathrm{~h}$ and then at $700{ }^{\circ} \mathrm{C}$ for $3 \mathrm{~h}$. The collected $\mathrm{BC}$ products were milled to pass through a $0.18-\mathrm{mm}$ sieve prior to sorption experiments.
Preparation of HMO-loaded BC

Hydrous-manganese-oxide-loaded $\mathrm{BC}$ was prepared by a conventional wet impregnation method. BC $(10.0 \mathrm{~g})$ was added to $200 \mathrm{~mL}$ of manganese nitrate solutions with different concentration $(0.002,0.01$, and $0.05 \mathrm{~mol} / \mathrm{L})$ and shocked at $150 \mathrm{rpm}$ for $12 \mathrm{~h}$. The filtered $\mathrm{Mn}$ (II)-impregnated $\mathrm{BC}$ samples were washed several times to remove uncombined $\mathrm{Mn}(\mathrm{II})$ cations on their surface and then transferred to $200 \mathrm{~mL}$ of potassium permanganate solution $(0.033 \mathrm{~mol} / \mathrm{L})$. The mixtures were further stirred for $24 \mathrm{~h}$ at $25{ }^{\circ} \mathrm{C}$. The chemical reactions involved can be described as follows:

$2 \mathrm{O}-\mathrm{COOH}+\mathrm{Mn}^{2+} \rightleftharpoons(\mathrm{O}-\mathrm{COO})_{2} \mathrm{Mn}+2 \mathrm{H}^{+}$

$(\mathrm{O}-\mathrm{COO})_{2} \mathrm{Mn}+\mathrm{MnO}_{4}^{-}+\mathrm{H}^{+} \longrightarrow \mathrm{O}-\mathrm{COOH}+\mathrm{HMO} \downarrow$

Note: $\mathrm{O}=$ Biochar matrix

After drying in a vacuum at $60{ }^{\circ} \mathrm{C}$ overnight, Mn-impregnated $\mathrm{BCs}$ were obtained and designated as $\mathrm{Mn} / \mathrm{BC}-0$, $\mathrm{Mn} / \mathrm{BC}$, and $\mathrm{Mn} / \mathrm{BC}-2$, which correspond to the solution concentrations of manganese nitrate $(0.002,0.01$, and $0.05 \mathrm{~mol} / \mathrm{L}$, respectively). The surface area and porosity of all of the samples were measured by nitrogen sorption at $77 \mathrm{~K}$ using a Micromeritics ASAP-2020 accelerated surface area and porosimetry analyzer (USA). Data were analyzed by the Brunauer-Emmett-Teller (BET) and $t$ plot methods. $\mathrm{X}$-ray powder diffraction (XRD) patterns of $\mathrm{BC}$ and HMOloaded BCs were obtained on an X'Pert PRO X-ray diffractometer (PANalytical, Holland) at $40 \mathrm{kV} / 40 \mathrm{~mA}$ using $\mathrm{Cu} K \alpha$ radiation $(\lambda=0.154 \mathrm{~nm})$. XRD patterns were recorded by step scanning from $10^{\circ}$ to $80^{\circ}$ ( $2 \theta$ angular range) with the sample spinning at $2 \mathrm{r} / \mathrm{s}$.

\section{Determination of manganese content on $\mathrm{BC}$}

Hydrous-manganese-oxide-loaded BCs (0.010 g) were added into digestion bottles containing a mixture of $10 \mathrm{~mL}$ of $\mathrm{HNO}_{3}(67 \%), 2 \mathrm{~mL}$ of $\mathrm{H}_{2} \mathrm{O}_{2}(30 \%), 2 \mathrm{~mL}$ of $\mathrm{HClO}_{4}$ $(70 \%)$, and $2 \mathrm{~mL}$ of $\mathrm{HF}(40 \%)$. All samples were digested in a microwave digestion instrument $\left(800 \mathrm{~W} ; 200{ }^{\circ} \mathrm{C} ; 800\right.$ psi; $60 \mathrm{~min}$ ). The decomposed solution was evaporated to less than $1 \mathrm{~mL}$ and then mixed with $0.5 \mathrm{~mL} \mathrm{HNO}_{3}$. The total volume of the solution was increased to $25 \mathrm{~mL}$ with distilled water. The manganese content $(\mathrm{Mn} \%)$ of the HMO-loaded BCs (Mn/BC-0, $\mathrm{Mn} / \mathrm{BC}$, and $\mathrm{Mn} / \mathrm{BC}-2)$ was determined from flame absorption measurements obtained using a PerkinElmer ${ }^{\circledR}$ AAnalyst ${ }^{\mathrm{TM}} 800$ atomic absorption 
spectrometer (USA) at a wavelength of $279.5 \mathrm{~nm}$. To evaluate the effect of the $\mathrm{Mn} \%$ loading on $\mathrm{Pb}$ (II) removal, the equilibrium sorption of $50 \mathrm{mg} / \mathrm{L} \mathrm{Pb}\left(\mathrm{NO}_{3}\right)_{2}(50 \mathrm{~mL})$ was determined in $100 \mathrm{~mL}$ conical flasks with HMO-free $\mathrm{BC}$ and HMO-loaded BC (0.050 g each).

\section{Sorption kinetics}

Preliminary kinetic experiments showed that $\mathrm{Pb}(\mathrm{II})$ sorption onto HMO-free BC and HMO-loaded BC reaches apparent equilibrium within $20 \mathrm{~h}$. To determine sorption kinetics, $\sim 0.005 \mathrm{~g}$ of $\mathrm{BC}$ and $\mathrm{Mn} / \mathrm{BC}$ were added to $21-\mathrm{mL}$ glass tubes. The sorption of $\mathrm{Pb}(\mathrm{II})$ in 0.0050 samples was measured at various time intervals by rotating with lots of $\mathrm{Pb}\left(\mathrm{NO}_{3}\right)_{2}$ solutions $(20 \mathrm{~mL}$, $50 \mathrm{mg} / \mathrm{L}$ ) in a $0.01 \mathrm{~mol} / \mathrm{L} \mathrm{NaNO}_{3}$ background electrolyte at $25^{\circ} \mathrm{C}$.

\section{Equilibrium sorption}

$\mathrm{Pb}$ (II) uptake was measured by the batch equilibration method. In brief, $\mathrm{BC}(\sim 0.05 \mathrm{~g})$ and HMO-loaded $\mathrm{BC}$ $(\sim 0.01 \mathrm{~g})$ were mixed with $20 \mathrm{~mL}$ of $\mathrm{Pb}\left(\mathrm{NO}_{3}\right)_{2}$ solution $(10-100 \mathrm{mg} / \mathrm{L})$ in $21-\mathrm{mL}$ glass tubes with $0.01 \mathrm{~mol} / \mathrm{L}$ $\mathrm{NaNO}_{3}$ to increase the ionic strength. All tubes were capped and rotated end-over-end at $40 \mathrm{rpm}$ for $48 \mathrm{~h}$ at 10,25 , and $40{ }^{\circ} \mathrm{C}$, respectively. The solution $\mathrm{pH}$ was adjusted by addition of $\mathrm{HNO}_{3}(0.01 \mathrm{~mol} / \mathrm{L})$ and $\mathrm{NaOH}$ $(0.01 \mathrm{~mol} / \mathrm{L})$ solution as necessary. The concentrations of $\mathrm{Pb}$ (II) in filtrates were analyzed using the flame atomic absorption spectrometer at a wavelength of $283.3 \mathrm{~nm}$. The amount of $\mathrm{Pb}(\mathrm{II})$ adsorbed by the carbons was calculated by conducting mass balance measurements of the solute before and after the test. All sorption experiments were performed in triplicate, and the data are expressed as mean values with maximum relative standard deviations (RSDs) lower than $\pm 2.1 \%$. Blank tests did not show any $\mathrm{Pb}(\mathrm{II})$ sorption on tube walls during the experiments.

\section{Results and discussion}

Screening of HMO-loaded BC for efficient removal of $\mathrm{Pb}(\mathrm{II})$

To assess the effect of HMO coating on the nature and sorption of $\mathrm{BC}$, a series of $\mathrm{Mn} / \mathrm{BC}$ samples was prepared by impregnating carbon with different amounts of $\mathrm{Mn}$ $(0.88,3.65$, and $9.96 \%)$. The X-ray diffraction patterns of $\mathrm{BC}$ and HMO-loaded $\mathrm{BC}$ are shown in Fig. 1. The original $\mathrm{BC}$ exhibited broad peaks at around 0.388 and $0.208 \mathrm{~nm}$, which are assigned to $h k l 002$ and overlapping

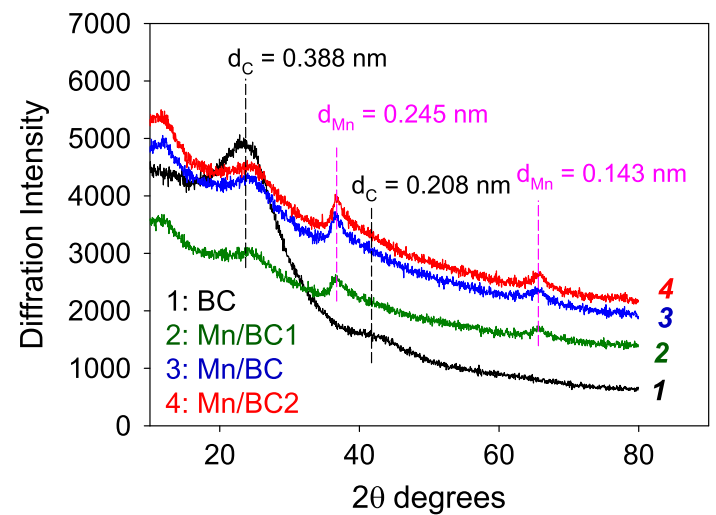

Fig. 1 XRD spectra of BC and HMO-loaded BC

101 and 100 planes, respectively (Keiluweit et al. 2010). For HMO-loaded BCs, the obvious decrease in the peak at $0.388 \mathrm{~nm}$ and disappearance of the peak at $0.208 \mathrm{~nm}$ indicates effective HMO loading on the BC surface. The emergence of new peaks $(d=0.245$ and $0.143 \mathrm{~nm})$ in all of the $\mathrm{Mn} / \mathrm{BC}$ samples over the whole range of $2 \theta$ degrees implies that HMO particles precipitate on the carbon surface, as is typical of $\delta-\mathrm{MnO}_{2}$ (Pretorius and Lindner 2001). A similar result was found by Lenoble et al. (2004), who successfully loaded $\delta-\mathrm{MnO}_{2}$ on the surface of polystyrene resin.

Selected physicochemical properties of HMO-free and all of the HMO-loaded BCs are listed in Table 1. The HMO-free BC is characterized with a BET surface area of $369 \mathrm{~m}^{2} / \mathrm{g}$, a micropore surface area of $203 \mathrm{~m}^{2} / \mathrm{g}$, and total pore and micropore volumes of 0.200 and $0.090 \mathrm{~cm}^{3} / \mathrm{g}$, respectively. These porous properties suggest that the original BC is an appropriate support for HMO loading. The larger the amount of Mn impregnated on the BC surface, the larger the amount of $\mathrm{Pb}$ (II) sorbed on the resulting material (Table 1). A minimal loading of Mn $(0.88 \%)$ increased the $\mathrm{Pb}(\mathrm{II})$ removal efficiency of the resulting $\mathrm{BC}$ material from 6.4 to $41.9 \%$. However, the excess coating with HMO leads to obvious pore blockage. For example, loading of HMO with $9.96 \% \mathrm{Mn}$ (i.e., $\mathrm{Mn} / \mathrm{BC}-2)$ resulted in a significant decrease in the surface area and pore volume of the resulting material by 82.1 and $72.5 \%$, respectively. In comparison, the $\mathrm{Mn} / \mathrm{BC}$ adsorbent impregnated with $3.65 \% \mathrm{Mn}$ yielded the optimal HMOBC composite, which has excellent removal efficiency of $\mathrm{Pb}$ (II) (Table 1). The SEM images demonstrate that micron-sized HMO particles are highly dispersed on the surface of $\mathrm{BC}$ after deposition of $3.65 \% \mathrm{Mn}$ onto the carbon support (Fig. 2). The concentration of surface hydroxyl groups also increased from 0.06 to $0.20 \mathrm{mmol} / \mathrm{g}$ (Table 1). This higher hydroxyl density results in the lower $\mathrm{pH}_{\mathrm{PZC}}$ value ( $\mathrm{pH}$ at the point of zero charge) of $\mathrm{BC}$, which is favorable for $\mathrm{Pb}$ (II) sorption. 
Table 1 Selected physicochemical properties of biochar (BC) and $\mathrm{Mn} / \mathrm{BC}$

\begin{tabular}{|c|c|c|c|c|c|c|c|c|}
\hline & $\operatorname{Mn} \%^{a}$ & $\begin{array}{l}S_{\mathrm{BET}}^{\mathrm{b}} \\
\left(\mathrm{m}^{2} / \mathrm{g}\right)\end{array}$ & $\begin{array}{l}S_{\text {micro }}^{\mathrm{c}} \\
\left(\mathrm{m}^{2} / \mathrm{g}\right)\end{array}$ & $\begin{array}{l}V_{\text {total }}^{\mathrm{d}} \\
\left(\mathrm{cm}^{3} / \mathrm{g}\right)\end{array}$ & $\begin{array}{l}V_{\text {micro }}^{\mathrm{e}} \\
\left(\mathrm{cm}^{3} / \mathrm{g}\right)\end{array}$ & $\begin{array}{l}\text { Surface hydroxyl } \\
(\mathrm{mmol} / \mathrm{g})\end{array}$ & $\mathrm{pH}_{\mathrm{PZC}}^{\mathrm{f}}$ & $\begin{array}{l}\text { Removal } \\
\text { efficiency }^{\mathrm{g}}(\%)\end{array}$ \\
\hline BC & 0 & $369 \pm 3.5$ & $203 \pm 2.6$ & $0.200 \pm 0.013$ & $0.090 \pm 0.006$ & $0.06 \pm 0.00$ & $4.5 \pm 0.1$ & 6.4 \\
\hline $\mathrm{Mn} / \mathrm{BC} 1$ & $0.88 \pm 0.03$ & $361 \pm 2.9$ & $209 \pm 2.5$ & $0.194 \pm 0.010$ & $0.094 \pm 0.005$ & ND & ND & 41.9 \\
\hline $\mathrm{Mn} / \mathrm{BC}$ & $3.65 \pm 0.11$ & $194 \pm 1.8$ & $74 \pm 0.7$ & $0.141 \pm 0.011$ & $0.030 \pm 0.002$ & $0.20 \pm 0.01$ & $3.2 \pm 0.1$ & 98.9 \\
\hline $\mathrm{Mn} / \mathrm{BC} 2$ & $9.96 \pm 0.30$ & $66 \pm 1.0$ & $34 \pm 0.5$ & $0.055 \pm 0.008$ & $0.015 \pm 0.001$ & ND & ND & 100 \\
\hline
\end{tabular}

$N D$ not determined

${ }^{a}$ The percentage content of $\mathrm{Mn}$ on $\mathrm{BC}$

${ }^{b}$ BET surface area

${ }^{c} t$ Plot micropore area

d Single point sorption total pore volume of pores

${ }^{\mathrm{e}} t$ Plot micropore volume

${ }^{\mathrm{f}} \mathrm{pH}$ of zero net charge point

g Removal efficiency of $\mathrm{Pb}(\mathrm{II})$ onto BC and HMO-loaded BC at $298 \mathrm{~K}$ (pH 5.00, the initial concentration of $\mathrm{Pb}(\mathrm{II})=80 \mathrm{mg} / \mathrm{l})$
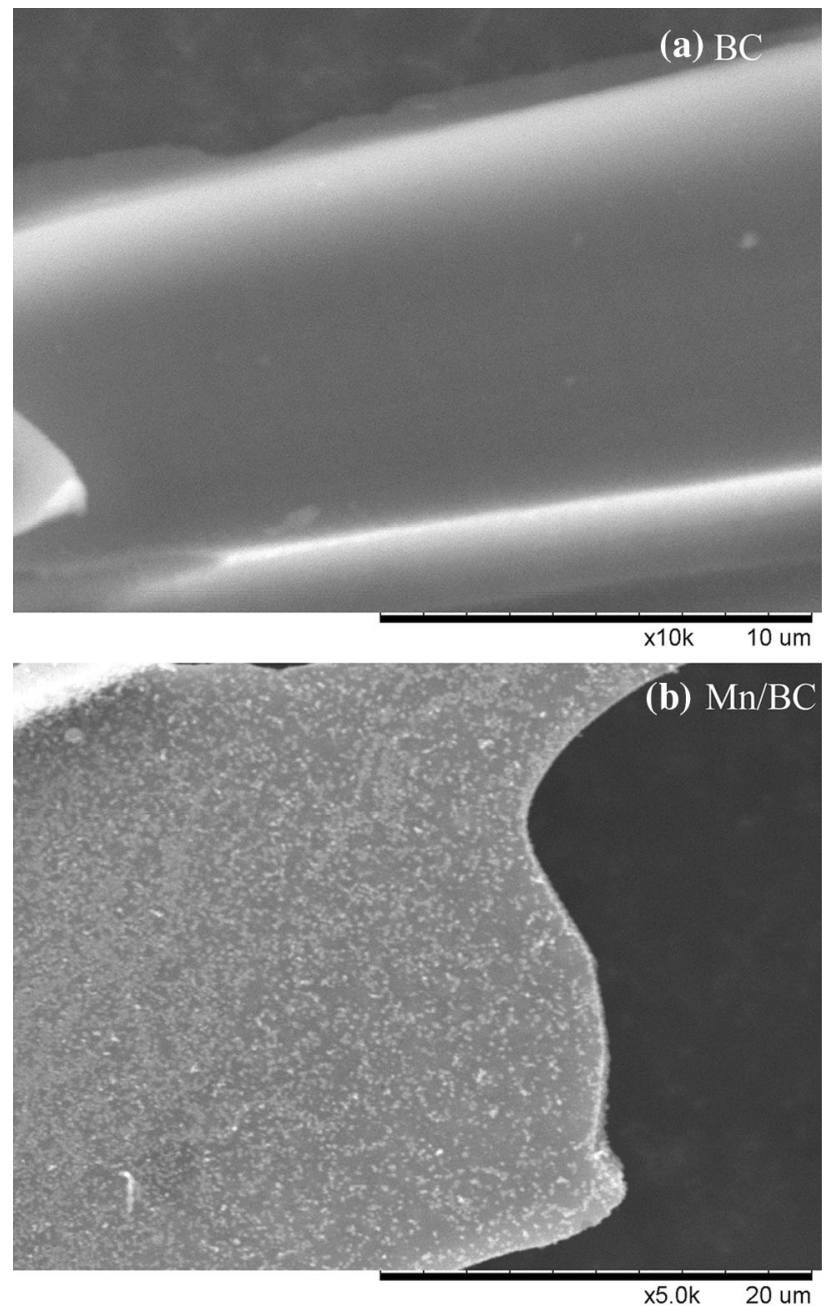

Fig. 2 SEM images of a $\mathrm{BC}$ and $\mathbf{b} \mathrm{Mn} / \mathrm{BC}$
Table 2 Chemical speciation of $\mathrm{Pb}(\mathrm{II})$ in $0.01 \mathrm{~mol} / \mathrm{L} \mathrm{NaNO}_{3}$ solution under the different $\mathrm{pH}$ at $25^{\circ} \mathrm{C}$

\begin{tabular}{lllll}
\hline $\mathrm{pH}$ & $\mathrm{Pb}^{2+}(\%)$ & $\mathrm{PbNO}_{3}{ }^{+}(\%)$ & $\mathrm{Pb}\left(\mathrm{NO}_{3}\right)_{2}(\mathrm{aq})(\%)$ & $\mathrm{PbOH}^{+}(\%)$ \\
\hline 1.73 & 92.252 & 7.652 & 0.097 & 0 \\
2.18 & 91.613 & 8.278 & 0.109 & 0 \\
2.72 & 91.298 & 8.586 & 0.116 & 0 \\
3.15 & 91.209 & 8.672 & 0.117 & 0 \\
3.93 & 91.153 & 8.714 & 0.118 & 0.014 \\
4.43 & 91.118 & 8.718 & 0.118 & 0.045 \\
4.65 & 91.089 & 8.716 & 0.118 & 0.075 \\
4.80 & 91.06 & 8.714 & 0.118 & 0.105 \\
5.00 & 91.002 & 8.709 & 0.118 & 0.167 \\
\hline
\end{tabular}

\section{Effect of $\mathrm{pH}$}

The solution $\mathrm{pH}$ influences both the $\mathrm{Pb}(\mathrm{II})$ species and the surface net charges on $\mathrm{Mn} / \mathrm{BC}$, which, in turn influences $\mathrm{Pb}$ (II) sorption. The speciation of $\mathrm{Pb}$ (II) in water with a ionic strength from $0.01 \mathrm{~mol} / \mathrm{L} \mathrm{NaNO}_{3}$ at different equilibrium $\mathrm{pH}$ can be described by MINTEQA2 model calculations (Qiu et al. 2008). At $\mathrm{pH} \leq 3.15$, three $\mathrm{Pb}$ (II) species $\left[\mathrm{Pb}^{2+}, \mathrm{PbNO}_{3}{ }^{+}\right.$, and $\left.\mathrm{Pb}\left(\mathrm{NO}_{3}\right)_{2}(\mathrm{aq})\right]$ are present in solution (Table 2). When the $\mathrm{pH}$ is increased from 3.93 to 5.00, an additional species $\left(\mathrm{PbOH}^{+}\right)$emerges. In the range of acidic $\mathrm{pH}$ (1.73-5.00), $\mathrm{Pb}(\mathrm{II})$ exists predominantly as $\mathrm{Pb}^{2+}(>91 \%)$ and $\mathrm{PbNO}_{3}{ }^{+}(>7.5 \%)$ cations and no $\mathrm{Pb}(\mathrm{II})$ hydroxide precipitate forms. Other $\mathrm{Pb}(\mathrm{II})$ species, including $\mathrm{Pb}\left(\mathrm{NO}_{3}\right)_{2}$ (aq) and $\mathrm{PbOH}^{+}$, present in solution can be ignored. This finding indicates that the uptake of $\mathrm{Pb}(\mathrm{II})$ by $\mathrm{Mn} / \mathrm{BC}$ depends completely on the effective combination of $\mathrm{Pb}^{2+}$ and $\mathrm{PbNO}_{3}{ }^{+}$cations on the surface binding sites. 


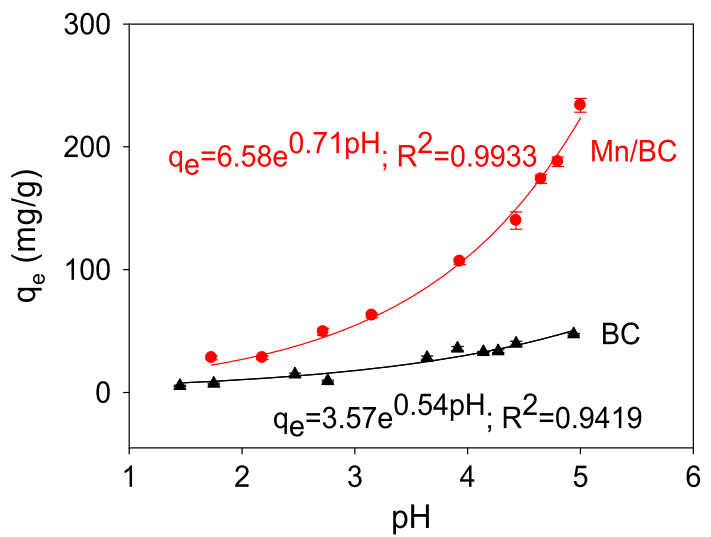

Fig. 3 pH-dependant uptake of $\mathrm{Pb}$ (II) on $\mathrm{BC}$ and $\mathrm{Mn} / \mathrm{BC}$ at $298 \mathrm{~K}$

After impregnating $\mathrm{BC}$ with $3.65 \% \mathrm{Mn}$, the $\mathrm{pH}_{\mathrm{PZC}}(\mathrm{pH}$ at the point of zero charge) of the carbons decreased from 4.5 to 3.2 , indicating the presence of more hydroxyl groups on the HMO-loaded surface. Early literatures show that the $\mathrm{pH}_{\mathrm{PZC}}$ values of amorphous HMO in solution are 2.4 (Eren et al. 2009) or 3.0 (Liu et al. 2009), which is also close to the $\mathrm{pH}_{\mathrm{PZC}}$ of $\mathrm{Mn} / \mathrm{BC}$ (3.2). The similarity of the $\mathrm{pH}_{\mathrm{PZC}}$ of the coated HMO on the carbon surface and the colloidal HMO in aqueous solution suggests that immobilization of HMO may not impact the sorption affinity of HMO for HMPs.

The $\mathrm{pH}$ dependence of the surface charges on $\mathrm{Mn} / \mathrm{BC}$ is due to the exchange of $\mathrm{H}^{+}$ions in aqueous solution, which can be illustrated as follows.

- $\mathrm{Mn}-\mathrm{OH}+\mathrm{H}_{2} \mathrm{O} \longrightarrow \mathrm{Mn}-\mathrm{OH}_{2}{ }^{+}+\mathrm{OH}^{-} \quad\left(\mathrm{pH}<\mathrm{pH}_{\mathrm{PZC}}\right)$

$-\mathrm{Mn}-\mathrm{OH} \longrightarrow \mathrm{On}_{-}^{-\mathrm{O}^{-}}+\mathrm{H}^{+} \quad\left(\mathrm{pH}>\mathrm{pH}_{\mathrm{PZC}}\right)$

Note: $=$ HMO-loaded biochar matrix

When $\mathrm{pH}<\mathrm{pH}_{\mathrm{PZC}}$, hydroxyl groups on the $\mathrm{Mn} / \mathrm{BC}$ surface are essentially protonated, resulting in a positively net charged surface. By contrast, deprotonation of the surface hydroxyl groups results in a negative net charge on the carbon surfaces (Han et al. 2006b).

The dependence of the uptake of $\mathrm{Pb}(\mathrm{II})$ by $\mathrm{Mn} / \mathrm{BC}$ on the solution $\mathrm{pH}$ is shown in Fig. 3. The equilibrium sorption capacity exponentially increased by 8.32 times when the solution $\mathrm{pH}$ was raised from 1.73 to 5.00 . This finding indicates that $\mathrm{Pb}(\mathrm{II})$-free cations in water can be appropriately adsorbed at high $\mathrm{pH}$, while sorbed $\mathrm{Pb}$ (II) on $\mathrm{Mn} /$ $\mathrm{BC}$ can be desorbed at low $\mathrm{pH}$. At equilibrium $\mathrm{pH}<\mathrm{pH}_{\mathrm{PZC}}$, electric repulsion between cationic $\mathrm{Pb}$ (II) species and positively charged carbon surfaces weakens the sorption affinity of $\mathrm{Pb}$ (II) to $\mathrm{Mn} / \mathrm{BC}$, the main driving force
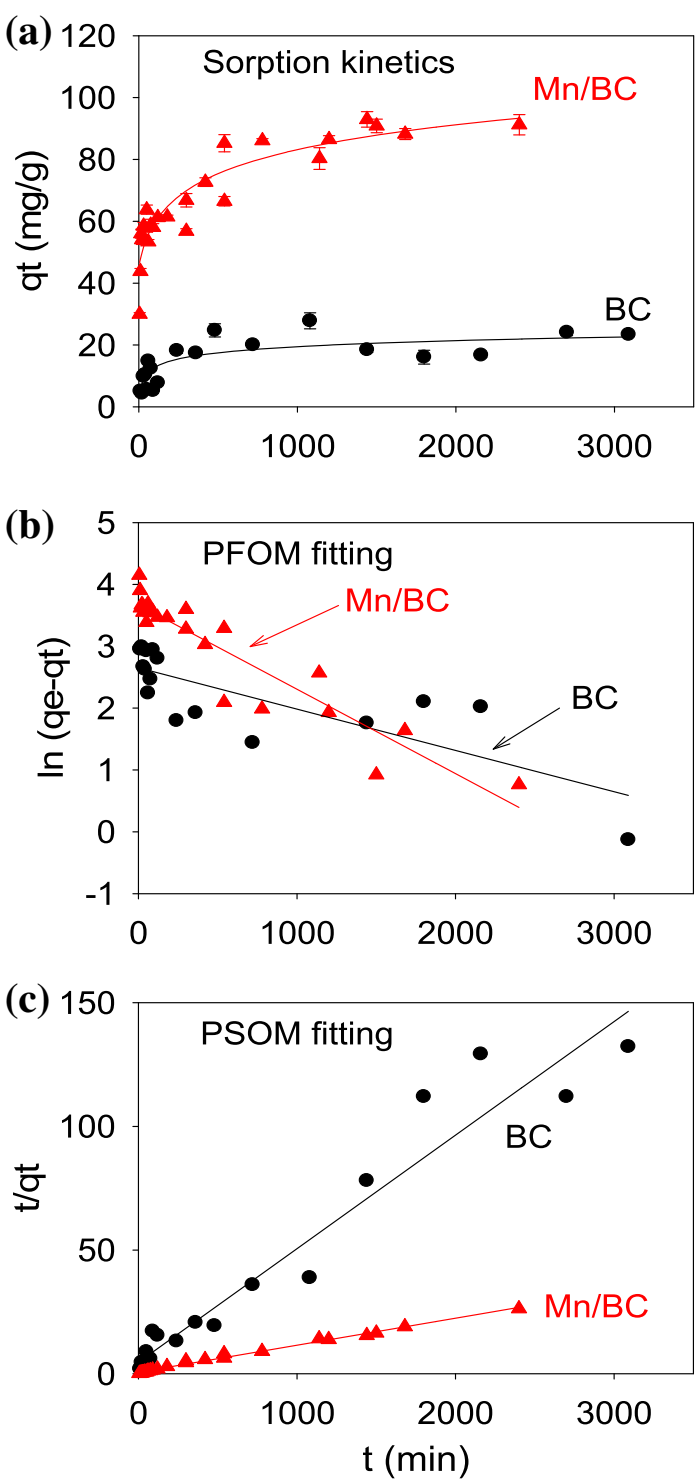

Fig. 4 a Sorption kinetics of $\mathrm{Pb}(\mathrm{II})$ on $\mathrm{BC}$ and $\mathrm{Mn} / \mathrm{BC}$ at $\mathrm{pH} 5.00$; the kinetic rates were modeled using $\mathbf{b}$ the pseudo-first-order model (PFOM) and $\mathbf{c}$ the pseudo-second-order model (PSOM)

of which is cation exchange between the protonated $\mathrm{Mn}$ / $\mathrm{BC}$ and cationic $\mathrm{Pb}$ (II) species (Qiu et al. 2008). When $\mathrm{pH}>\mathrm{pH}_{\mathrm{PZC}}$, electrostatic interactions between $\mathrm{Pb}^{2+} /$ $\mathrm{PbNO}_{3}{ }^{+}$cations and the negative charge sites of $\mathrm{Mn} / \mathrm{BC}$ play a dominant role in $\mathrm{Pb}$ (II) sorption. The corresponding sorption mechanism is illustrated as follows.

$20-\mathrm{Mn}-\mathrm{O}^{-}+\mathrm{Pb}^{2+} \longrightarrow \mathrm{Mn}-\mathrm{O}-\mathrm{Pb}-\mathrm{O}-\mathrm{Mn}-\mathrm{O}$

$-\mathrm{Mn}-\mathrm{O}^{-}+\mathrm{Pb}\left(\mathrm{NO}_{3}\right)^{+} \longrightarrow \mathrm{Mn}-\mathrm{O}-\mathrm{Pb}\left(\mathrm{NO}_{3}\right)$ 
Table 3 Kinetic parameters of pseudo-second-order model (PSOM) and pseudo-first-order model (PFOM) for sorption of Pb(II) on biochar (BC) and $\mathrm{Mn} / \mathrm{BC}$ at $313 \mathrm{~K}$

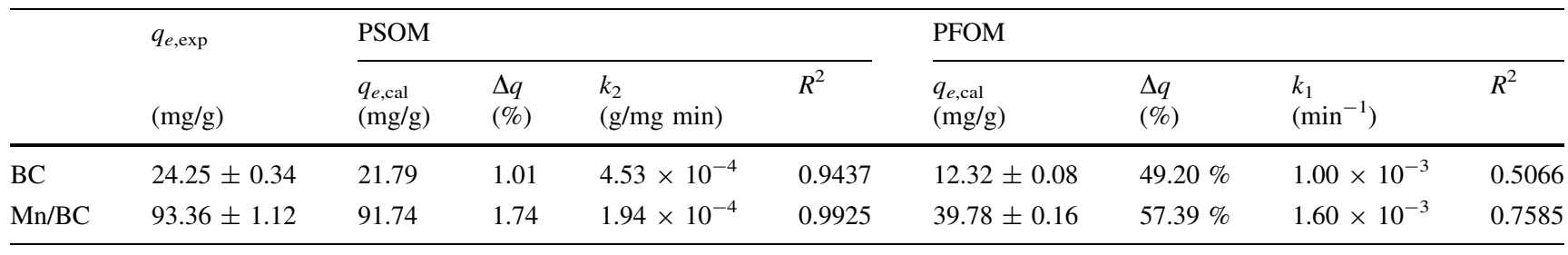

\section{Sorption kinetics}

To evaluate differences in $\mathrm{Pb}$ (II) sorption kinetic rates on $\mathrm{BC}$ and $\mathrm{Mn} / \mathrm{BC}$ and describe the kinetic sorption process, a pseudo-first-order model (PFOM) and a pseudo-secondorder model (PSOM) were employed (Fig. 4). The PSOM assumes that the rate-limiting step is chemical sorption involving valence forces through the sharing or exchange of electrons between the sorbent and sorbate (Ho and McKay 1999). By contrast, the PFOM uses the sorption capacity of sorbents as basis for predicting the rate of sorption (Qiu et al. 2009b). The two kinetic models are presented as follows (Sharaf and Hassan 2013):

PFOM : $\ln \left(1-\frac{q_{t}}{q_{e}}\right)=-k_{1} t$

PSOM : $\frac{t}{q_{t}}=\frac{1}{k_{2} q_{e}^{2}}+\frac{1}{q_{e}} \cdot t$

where $q_{t}$ and $q_{e}(\mathrm{mg} / \mathrm{g})$ are the uptake of $\mathrm{Pb}(\mathrm{II})$ at time $t(\mathrm{~min})$ and equilibrium, respectively, and $k_{1}$ and $k_{2}$ are the first-order $(1 / \mathrm{min})$ and second-order $(\mathrm{g} / \mathrm{mg} \mathrm{min})$ rate constants, respectively. The calculated kinetics parameters are presented in Table 3. Clearly, the PSOM fits the sorption data of $\mathrm{BC}$ and $\mathrm{Mn} / \mathrm{BC}$ well, as evidenced by the higher $R^{2}$ values (the square of the regression coefficient) of PSOM compared with PFOM.

To quantitatively compare the applicability of these two models, the normalized standard deviation $\Delta q(\%)$ was calculated using the following formula ( $\mathrm{Lv}$ et al. 2007).

$\Delta q(\%)=100 \times \sqrt{\frac{\sum\left[\left(q_{e, \exp }-q_{e, \text { al }}\right) / q_{e, \exp }\right]^{2}}{n-1}}$

where $q_{e, \text { exp }}$ and $q_{e, \text { cal }}(\mathrm{mg} / \mathrm{g})$ are the experimental and calculated equilibrium sorption of $\mathrm{Pb}(\mathrm{II})$ on carbons, respectively, and $\mathrm{n}$ is the number of measurements. The smaller $\Delta q$ values of $\mathrm{BC}$ and $\mathrm{Mn} / \mathrm{BC}$ from PSOM (1.01 and $1.74 \%)$ compared with those from PFOM (49.20 and $57.39 \%$ ) further indicate that the sorption of $\mathrm{Pb}(\mathrm{II})$ may be better described by PSOM kinetics (Şölener et al. 2008). Generally, a larger $k_{2}$ value means a slower sorption rate (Maliyekkal et al. 2006; Fan et al. 2003). The $k_{2}$ value of $\mathrm{Mn} / \mathrm{BC}\left(1.94 \times 10^{-4} \mathrm{~g} / \mathrm{mg} \mathrm{min}\right)$ in this experiment was

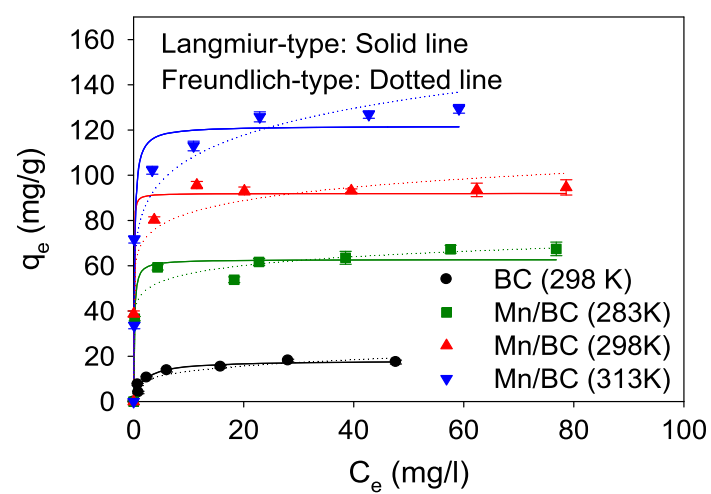

Fig. 5 Langmuir and Freundlich adsorption isotherm of $\mathrm{Pb}(\mathrm{II})$ on $\mathrm{BC}$ at $298 \mathrm{~K}$ and onto $\mathrm{Mn} / \mathrm{BC}$ at 283,298 , and $313 \mathrm{~K}$, respectively $(\mathrm{pH}$ 5.00)

2.33 times lower than that of $\mathrm{BC}\left(4.53 \times 10^{-4} \mathrm{~g} / \mathrm{mg} \mathrm{min}\right)$, indicating that the sorption rate of $\mathrm{Mn} / \mathrm{BC}$ is faster than that of BC. Table 1 shows that the micropore area of $\mathrm{Mn} / \mathrm{BC}$ $\left(74 \mathrm{~m}^{2} / \mathrm{g}\right.$ ) accounts for only $38.1 \%$ of the total surface area of the resulting material. Thus, most of the sorption sites on $\mathrm{Mn} / \mathrm{BC}$ may be in mesopore and macropore regions that are easily accessible for $\mathrm{Pb}(\mathrm{II})$ sorption. By contrast, the micropore areas of original $\mathrm{BC}$ accounted for over $50 \%$ of the total surface area of the material. Therefore, the sorption rate of $\mathrm{Pb}(\mathrm{II})$ on $\mathrm{BC}$ must be slower than that on $\mathrm{Mn} /$ $\mathrm{BC}$ because most of the $\mathrm{Pb}(\mathrm{II})$ cations must diffuse into the micropore regions to combine with sorption sites. Similar findings were showed in the previous study, which found that micropores of Mn-impregnated AC derived from $T y$ pha orientalis do not contribute to the sorption of neutral red dye (Zhang et al. 2008). Moreover, the faster sorption rate of $\mathrm{Mn} / \mathrm{BC}$ compared with that of original $\mathrm{BC}$ may be attributed to the higher availability of sorption sites on the surface of $\mathrm{Mn} / \mathrm{BC}$. This explanation is in agreement with other reports (Guo et al. 2011; Reddad et al. 2002).

\section{Sorption isotherms}

The sorption isotherms of $\mathrm{Pb}$ (II) on $\mathrm{BC}$ at $298 \mathrm{~K}$ and $\mathrm{Mn} /$ $\mathrm{BC}$ at three different temperatures are shown in Fig. 5. The sorption capacities of $\mathrm{Pb}(\mathrm{II})$ on $\mathrm{Mn} / \mathrm{BC}$ increased markedly with the increase in environmental temperature, indicating 
Table 4 Langmuir and Freundlich parameters for sorption of the biochar (BC) and Mn/BC

\begin{tabular}{|c|c|c|c|c|c|c|}
\hline \multirow[t]{2}{*}{ Adsorbents } & \multicolumn{3}{|c|}{ Langmuir model } & \multicolumn{3}{|c|}{ Freundlich model } \\
\hline & $K_{\mathrm{L}}$ & $q_{\mathrm{m}}$ & $R^{2}$ & $K_{\mathrm{F}}$ & $1 / n$ & $R^{2}$ \\
\hline BC $(298 \mathrm{~K})$ & $0.57 \pm 0.13$ & $18.13 \pm 0.94$ & 0.9639 & $7.77 \pm 1.01$ & $0.235 \pm 0.043$ & 0.9268 \\
\hline $\mathrm{Mn} / \mathrm{BC}(283 \mathrm{~K})$ & $7.45 \pm 2.28$ & $62.77 \pm 1.89$ & 0.9672 & $45.80 \pm 2.61$ & $0.091 \pm 0.017$ & 0.9753 \\
\hline $\mathrm{Mn} / \mathrm{BC}(298 \mathrm{~K})$ & $34.3 \pm 7.76$ & $91.98 \pm 2.05$ & 0.9830 & $67.18 \pm 4.19$ & $0.093 \pm 0.018$ & 0.9660 \\
\hline $\mathrm{Mn} / \mathrm{BC}(313 \mathrm{~K})$ & $5.92 \pm 1.85$ & $121.8 \pm 5.82$ & 0.9436 & $77.76 \pm 6.63$ & $0.138 \pm 0.026$ & 0.9407 \\
\hline
\end{tabular}

a typical chemical sorption process between the adsorbate and adsorbent (Aksu 2002). The experimental data were analyzed using the Langmuir and Freundlich models, which are expressed as follows:

Langmuir model: $\quad q_{e}=\frac{q_{\mathrm{m}} K_{\mathrm{L}} C_{e}}{1+K_{\mathrm{L}} C_{e}}$

Reundlich model: $q_{e}=K_{\mathrm{F}} C_{e}^{1 / n}$

where $q_{e}(\mathrm{mg} / \mathrm{g})$ is the equilibrium sorption of $\mathrm{Pb}(\mathrm{II}), q_{\mathrm{m}}$ $(\mathrm{mg} / \mathrm{g})$ is the maximum $\mathrm{Pb}(\mathrm{II})$ sorption corresponding to complete monolayer coverage, $K_{\mathrm{L}}(1 / \mathrm{mg})$ denotes the affinity of binding sites and $K_{\mathrm{F}}$ and $1 / n$ indicate the sorption capacity and intensity, respectively (Shuang et al. 2012). The equilibrium data fit the Langmuir model well, thus implying that sorbed $\mathrm{Pb}^{2}+$ and $\mathrm{PbNO}_{3}{ }^{+}$cations form monolayer coverage on the carbon surface. The sorption data of $\mathrm{Mn} / \mathrm{BC}$ also fit the Freundlich model well, which is likely due to the heterogeneous nature of surface sites of $\mathrm{Mn} / \mathrm{BC}$ involved in the $\mathrm{Pb}$ (II) uptake (Reddad et al. 2002). The fitted values of the Langmuir and Freundlich parameters are presented in Table 4. The maximum monolayer sorption $\left(q_{\mathrm{m}}\right)$ of $\mathrm{Mn} / \mathrm{BC}$ at $298 \mathrm{~K}$ was five times larger than that of $\mathrm{BC}$, which can be attributed to the larger number of surface hydroxyl groups and lower $\mathrm{pH}_{\mathrm{PZC}}$ of $\mathrm{Mn} / \mathrm{BC}$. These findings indicate that the $\mathrm{Mn} / \mathrm{BC}$ composite fabricated in the present study is an effective adsorbent for $\mathrm{Pb}$ (II) removal from aqueous solutions.

To further evaluate the sorption mechanism of $\mathrm{Pb}$ (II) on $\mathrm{Mn} / \mathrm{BC}$, sorption thermodynamics under different temperatures $(283,298$, and $313 \mathrm{~K}$ ) was studied. According to the Van't Hoff equation, the thermodynamic parameters $(\Delta H$, $\Delta G$, and $\Delta S$ ) can be calculated using the sorption equilibrium constant $\left(K_{\mathrm{F}}\right)$ obtained from the Freundlich isotherm (Wu et al. 2011) (Table 5).

$$
\begin{aligned}
& \ln K_{\mathrm{F}}=-\frac{\Delta H}{R T}+\frac{\Delta S}{R} \\
& \Delta G=-R T \ln K_{\mathrm{F}} \\
& \Delta S=\frac{\Delta H-\Delta G}{T}
\end{aligned}
$$

where $\Delta H$ is the change in enthalpy $(\mathrm{kJ} / \mathrm{mol}), \Delta S$ is the change in entropy $(\mathrm{J} / \mathrm{mol} \mathrm{K}), \Delta G$ is the change in standard
Table 5 Thermodynamic parameters for sorption of $\mathrm{Pb}(\mathrm{II})$ on $\mathrm{Mn} /$ $\mathrm{BC}$

\begin{tabular}{llll}
\hline$T(\mathrm{~K})$ & $\Delta G(\mathrm{~kJ} / \mathrm{mol})$ & $\Delta H(\mathrm{~kJ} / \mathrm{mol})$ & $\Delta S(\mathrm{~J} / \mathrm{mol} \mathrm{K})$ \\
\hline 283 & $-9.00 \pm 0.14$ & $13.10 \pm 0.75$ & $78.27 \pm 3.31$ \\
298 & $-10.60 \pm 0.15$ & $13.10 \pm 0.75$ & $78.92 \pm 3.02$ \\
313 & $-11.33 \pm 0.23$ & $13.10 \pm 0.75$ & $78.22 \pm 3.29$ \\
\hline
\end{tabular}

Gibbs free energy $(\mathrm{kJ} / \mathrm{mol}), T(\mathrm{~K})$ is the absolute temperature $(\mathrm{K})$ and $R$ is the gas constant $(8.314 \mathrm{~J} / \mathrm{mol} \mathrm{K})$. The negative values of $\Delta G$ at three temperatures verify the spontaneous nature of sorption of $\mathrm{Pb}(\mathrm{II})$ on $\mathrm{Mn} / \mathrm{BC}$. Moreover, the decrease $\Delta G$ value with the increase in solution temperature suggests that adsorption was more spontaneous at high temperature (Table 5). The positive value of $\Delta H(13.10 \pm 0.75 \mathrm{~kJ} / \mathrm{mol})$ indicates that the sorption reaction is endothermic in nature. The positive value of $\Delta S$ shows the increasing randomness of sorbates and solutes during the sorption processes, which may be due to the sorbed $\mathrm{Pb}^{2+}$ and $\mathrm{PbNO}_{3}{ }^{+}$-hydrated cations may displace a considerable number of water molecules (Lin and Teng 2002).

\section{Conclusion}

The present study demonstrated that the loading of HMO onto $\mathrm{BC}$ markedly increases $\mathrm{Pb}$ (II) uptake from aqueous solutions. In comparison with the original BC, the HMOBC composite impregnated with $3.65 \% \mathrm{Mn}$ not only showed enhanced adsorption capacity for $\mathrm{Pb}$ (II) but also indicated an accelerated sorption rate for $\mathrm{Pb}(\mathrm{II})$. $\mathrm{An}$ increase in $\mathrm{pH}$ enhanced electrostatic interactions between $\mathrm{Pb}$ (II) and the $\mathrm{Mn} / \mathrm{BC}$ surface. The negative value of $\Delta G$ and positive value of $\Delta H$ indicated that the $\mathrm{Pb}(\mathrm{II})$ sorption process is spontaneous and endothermic. Therefore, HMO-loaded $\mathrm{BC}$ is an effective adsorbent for removing $\mathrm{Pb}(\mathrm{II})$ from water.

Acknowledgments This research was supported by the National Natural Science Foundation of China (No. 21177113). 


\section{References}

Aksu Z (2002) Determination of the equilibrium, kinetic and thermodynamic parameters of the batch biosorption of lead (II) ions onto Chlorella vulgaris. Process Biochem 38:89-99

Cao XD, Ma LN, Gao B, Harris W (2009) Dairy-manure derived biochar effectively sorbs lead and atrazine. Environ Sci Technol 43:3285-3291

Chen ZM, Chen BL, Chiou CT (2012) Fast and slow rates of naphthalene sorption to biochars produced at different temperatures. Environ Sci Technol 46:11104-11111

Chun Y, Sheng G, Chiou CT, Xing BS (2004) Compositions and sorptive properties of crop residue-derived chars. Environ Sci Technol 38:4649-4655

Considine R, Denoyel R, Pendleton P, Schumann R, Wong SH (2001) The influence of surface chemistry on activated carbon adsorption of 2-methylisoborneol from aqueous solution. Colloid Surf A 179:271-280

Eren E, Afsin B, Onal Y (2009) Removal of lead ions by acid activated and manganese oxide-coated bentonite. J Hazard Mater 161:677-685

Fan HJ, Anderson PR (2005) Copper and cadmium removal by Mn oxide-coated granular activated carbon. Sep Purif Technol 45:61-67

Fan X, Parker DJ, Smith MD (2003) Adsorption kinetics of fluoride on low cost materials. Water Res 37:4929-4937

Fraser B (2010) High-tech charcoal fights climate change. Environ Sci Technol 44:548-549

Guo HM, Li Y, Zhao K, Ren Y, Wei C (2011) Removal of arsenite from water by synthetic siderite: behaviors and mechanisms. J Hazard Mater 186:1847-1854

Han RP, Zou WH, Li HK, Li YH, Shi J (2006a) Copper(II) and lead(II) removal from aqueous solution in fixed-bed columns by manganese oxide coated zeolite. J Hazard Mater 137:934-942

Han RP, Zou WH, Zhang ZP, Shi J, Yang JJ (2006b) Removal of copper(II) and lead(II) from aqueous solution by manganese oxide coated sand I. characterization and kinetic study. J Hazard Mater 137:384-395

Ho YS, McKay G (1999) Pseudo-second order model for sorption processes. Process Biochem 34:451-465

Keiluweit M, Nico PS, Johnson MG, Kleber M (2010) Dynamic molecular structure of plant biomass-derived black carbon (biochar). Environ Sci Technol 44:1247-1253

Kong HL, He J, Gao YZ, Wu HF, Zhu XZ (2011) Cosorption of phenanthrene and mercury (ii) from aqueous solution by soybean stalk-based biochar. J Agric Food Chem 59:12116-12123

Lenoble V, Laclautre C, Serpaud B, Deluchat V, Bollinger JC (2004) $\mathrm{As}(\mathrm{V})$ retention and $\mathrm{As}(\mathrm{III})$ simultaneous oxidation and removal on a $\mathrm{MnO}_{2}$-loaded polystyrene resin. Sci Total Environ 326:197-207

Lin YR, Teng HS (2002) Mesoporous carbons from waste tire char and their application in wastewater discoloration. Micropor Mesopor Mater 54:167-174

Liu RP, Liu HJ, Qiang ZM, Qu JH, Li GB, Wang DS (2009) Effects of calcium ions on surface characteristics and adsorptive properties of hydrous manganese dioxide. J Colloid Interf Sci 331:275-280

Lv L, He J, Wei M, Evans DG, Zhou ZL (2007) Treatment of high fluoride concentration water by $\mathrm{MgAl}-\mathrm{CO} 3$ layered double hydroxides: kinetic and equilibrium studies. Water Res 41:1534-1542

Maliyekkal MS, Sharma AK, Philip L (2006) Manganese-oxidecoated alumina: a promising sorbent for defluoridation of water. Water Res 40:3497-3506

Pretorius PJ, Lindner PW (2001) The adsorption characteristics of $\delta$ manganese dioxide: a collection of diffuse double layer constants for the adsorption of $\mathrm{H}^{+}, \mathrm{Cu}^{2+}, \mathrm{Ni}^{2+}, \mathrm{Zn}^{2+}, \mathrm{Cd}^{2+}$ and $\mathrm{Pb}^{2+}$. Appl Geochem 16:1067-1082

Qiu YP, Cheng HY, Xu C, Sheng GD (2008) Surface characteristics of crop-residue-derived black carbon and lead(II) adsorption. Water Res 42:567-574

Qiu H, Pan BC, Zhang QJ, Zhang WM, Zhang QX (2009a) Critical review in adsorption kinetic models. J Zhejiang Univ Sci A 10:716-724

Qiu YP, Zheng ZZ, Zhou ZL, Sheng GD (2009b) Effectiveness and mechanisms of dye adsorption on a straw-based biochar. Bioresour Technol 100:5348-5351

Reddad Z, Gerente C, Andres Y, Cloirec PL (2002) Adsorption of several metal ions onto a low-cost biosorbent: kinetic and equilibrium studies. Environ Sci Technol 36:2067-2073

Sharaf G, Hassan H (2013) Removal of copper ions from aqueous solution using silica derived from rice straw: comparison with activated charcoal. Int J Environ Sci Technol. doi:10.1007/ s13762-013-0343-8

Shuang CD, Li PH, Li AM, Zhou Q, Zhang MC, Zhou Y (2012) Quaternized magnetic microspheres for the efficient removal of reactive dyes. Water Res 46:4417-4426

Şölener M, Tunali S, Özcan AS, Özcan A, Gedikbey T (2008) Adsorption characteristics of lead(II) ions onto the clay/ poly(methoxyethyl)acrylamide (PMEA) composite from aqueous solutions. Desalination 223:308-322

Su Q, Pan BC, Pan BJ, Zhang QR, Zhang WM, LV L, Wang XS, Wu J, Zhang QX (2009) Fabrication of polymer-supported nanosized hydrous manganese dioxide (HMO) for enhanced lead removal from waters. Sci Total Environ 407:5471-5477

Thipnakarin B, Axe L, Xu Y, Tyson TA (2006) Nickel and lead sequestration in manganese oxide-coated montmorillonite. J Colloid Interf Sci 303:87-98

Uchimiya M, Chang S, Klasson KT (2011) Screening biochars for heavy metal retention in soil: role of oxygen functional groups. J Hazard Mater 190:432-441

Vasudevan D, Dorley PJ, Zhuang X (2001) Adsorption of hydroxy pyridines and quinolines at the metal oxide-water interface: role of tautomeric equilibrium. Environ Sci Technol 35:2006-2013

Wang SG, Gong WX, Liu XW, Yao YW, Gao BY, Yue QY (2007) Synthesis and characterization of manganese dioxide spontaneously coated on carbon nanotubes. Sep Purif Technol 58:17-23

Wang Y, Wang L, Fang GD, Herath HMSK, Wang YJ, Cang L, Xie ZB, Zhou DM (2013) Enhanced PCBs sorption on biochars as affected by environmental factors: humic acid and metal cations. Environ Pollut 72:86-93

Wu XQ, Xiao BD, Li RH, Wang CB, Huang JT, Wang Z (2011) Mechanisms and factors affecting sorption of microcystins onto natural sediments. Environ Sci Technol 45:2641-2647

Zhang J, Shi QQ, Zhang CL, Xu JT, Zhai B, Zhang B (2008) Adsorption of neutral red onto Mn-impregnated activated carbons prepared from Typha orientalis. Bioresour Technol 99:8974-8980 